\title{
MENINGKATKAN ORIENTASI PILIHAN KARIER MELALUI LAYANAN BIMBINGAN KELOMPOK DENGAN TEKNIK PROBLEM SOLVING PADA SISWA KELAS XII TPM 2 SMK NEGERI 1 TRENGGALEK TAHUN PELAJARAN 2016/2017
}

\author{
PRAPTANTI DYAH FITRIANA \\ SMK Negeri 1 Trenggalek \\ praptanti270587@gmail.com
}

\begin{abstract}
ABSTRAK
Mengingat pentingnya masalah karier dalam kehidupan manusia, maka sejak dini siswa perlu dipersiapkan dan dibantu untuk merencanakan tentang kariernya. Hal ini bisa dilakukan dengan cara memberikan pendidikan dan pemahaman orientasi karier yang berkelanjutan. Menyadari keadaan yang demikian maka perlu dilaksanakan bimbingan karier yang menekankan kegiatan- kegiatan dan informasi yang sistematis tentang dunia kerja dan alternatif pendidikan dimasa yang akan datang. Rumusan masalah dalam penelitian ini adalah "Apakah layanan bimbingan kelompok dengan teknik problem solving dapat meningkatkan orientasi pilihan karier siswa kelas XII TPm 2 SMK Negeri 1 Trenggalek tahun pelajaran 2016/2017". Tujuan dari penelitian ini adalah untuk mengetahui penerapan layanan bimbingan kelompok dengan teknik problem solving dalam meningkatkan orientasi pilihan karier siswa kelas XII TPm 2 SMK Negeri 1 Trenggalek tahun pelajaran 2016/2017. Adapun jenis penelitian yang digunakan dalam penelitian ini adalah penelitian tindakan bimbingan konseling (PTBK). Subjek dalam penelitian ini adalah siswa kelas XII TPm 2 SMK Negeri 1 Trenggalek tahun pelajaran 2016/2017 yang berjumlah 36 siswa. Metode pengumpulan data dalam penelitian ini adalah angket dan observasi.Hasil analisis data menunjukkan bahwa terjadi peningkatan orientasi pilihan karier siswa setelah dilakukan bimbingan kelompok dengan teknik problem solving. Data yang diperoleh menunjukkan adanya peningkatan orientasi pilihan karier pada siswa dari yang semula frekuensi orientasi pilihan karier hanya $69,44 \%$ (pada siklus I) dengan kriteria rendah, meningkat menjadi $88,89 \%$ (pada siklus II) termasuk dalam kriteria tinggi. Pada siklus 2, indikator keberhasilan yang sudah direncanakan di awal penelitian telah tercapai. Kesimpulan dari penelitian ini adalah bimbingan kelompok dengan teknik problem solving dapat meningkatkan orientasi pilihan karier siswa kelas XII TPm 2 SMK Negeri 1 Trenggalek tahun pelajaran 2016/2017, sehingga hipotesis yang diajukan di awal penelitian ini dapat diterima.
\end{abstract}

Cara mengutip: Fitriana, Praptanti D. (2018) Meningkatkan Orientasi Pilihan Karier Melalui Layanan Bimbingan Kelompok dengan Teknik Problem Solving pada Siswa Kelas XII TPM 2 SMK Negeri 1 Trenggalek Tahun Pelajaran 2016/2017. Jurnal Nusantara of Research, 5(2), 44-52.

\section{PENDAHULUAN}

Pendidikan mempunyai peranan yang sangat penting dalam rangka meningkatkan kualitas Sumber Daya Manusia (SDM). Dengan pendidikan diharapkan siswa akan memperoleh berbagai macam kemampuan, pengetahuan, keterampilan serta keahlian. Dengan bekal tersebut, diharapkan siswa akan mampu memilih, menetapkan dan mempersiapkan diri untuk memasuki dunia kerja yang sesuai dengan tuntutan hidup, cita-cita dan nilai-nilai hidup yang dianutnya sendiri. Sekolah Menengah Kejuruan (SMK) merupakan lembaga pendidikan yang 
menyiapkan tenaga terampil untuk memasuki dunia kerja dengan pemenuhan kompetensi di berbagai bidang. Siswa diberi beberapa alternatif pilihan kompetensi keahlian yang dapat mewadahi bakat dan minat siswa yang selanjutnya didayagunakan untuk membentuk pribadi siswa dalam rangka persiapan memasuki dunia kerja.

SMK adalah lembaga pendidikan tingkat menengah yang diharapkan dapat menghasilkan tenaga kerja atau Sumber Daya Manusia (SDM) yang profesional di bidangnya agar mampu tetap berkiprah dalam memenuhi kebutuhan tenaga kerja di Dunia Usaha/ Dunia Industri (DU/DI). Karier bagi siswa bukanlah hal yang mudah untuk ditentukan dan menjadi pilihan yang sesuai dengan kemampuan. Persiapan diri dan pemilihan dalam menjalankan suatu pekerjaan atau karier merupakan salah satu tugas perkembangan yang penting di masa remaja. Masa remaja merupakan masa transisi menuju kedewasaan, begitu juga dalam berkarier. Berkarier sendiri merupakan salah satu penanda masuknya seseorang ke dalam gaya hidup orang dewasa. Remaja pada masa ini dihadapkan pada situasi dimana mereka diharuskan membuat pilihan karier tanpa memiliki banyak pengalaman di dalam dunia pekerjaan (Newman \& Newman,1979 dalam Slameot, 2008).

Kesulitan siswa dalam memilih dan menentukan karier tidaklah dapat dipungkiri. Banyak siswa yang tidak mengetahui bahwa karier adalah jalan hidup dalam usaha menggapai kehidupan yang baik di masa mendatang. Permasalahan yang terjadi (Slamet, 2008) diantaranya adalah: (1) belum memiliki pemahaman yang mantap tentang kelanjutan pendidikan setelah lulus, (2) kompetensi keahlian yang dimasuki bukan pilihan sendiri, (3) belum memahami jenis pekerjaan yang cocok sesuai kemampuan diri sendiri, (4) masih bingung memilih jenis pekerjaan yang sesuai dengan minat dan kemampuan, (5) merasa pesimis bahwa setelah lulus akan mendapatkan pekerjaan yang diinginkan.

Sebagian besar siswa kelas XII TPm 2 SMK Negeri 1 Trenggalek memiliki kesulitan memilih dan menentukan karier. Hal tersebut berdasarkan hasil analisis iventori Daftar Cek Masalah (DCM) yang dikerjakan oleh siswa dan didapatkan data prosentase tinggi untuk masalah "Pekerjaan dan Cita-cita". Dari total 36 siswa di kelas, sebanyak 85,7\% (30 siswa) membutuhkan latihan kerja selain pelajaran yang ada; $94,2 \%$ (33 siswa) merasa harus memilih meneruskan pekerjaan pada tahun berikutnya; 94,2 \% (33 siswa) merasa takut tidak mendapatkan pekerjaan dan sebanyak 85,7\% (30 siswa) tidak tahu bagaimana mencari pekerjaan setelah lulus. Selain itu, dari hasil wawancara yang dilakukan konselor kepada siswa didapatkan data bahwa siswa merasa kesulitan dan bimbang dalam memilih pekerjaan yang sesuai untuk masa depannya dan bingung antara memilih bekerja atau meneruskan pendidikan ke perguruan tinggi.

Mengingat pentingnya masalah karier dalam kehidupan manusia, maka sejak dini siswa perlu dipersiapkan dan dibantu untuk merencanakan kariernya. Hal ini bisa dilakukan dengan cara memberikan pendidikan dan pemahaman orientasi karier yang berkelanjutan. Menyadari keadaan yang demikian maka perlu dilaksanakan bimbingan karier yang menekankan kegiatan- kegiatan dan informasi yang sistematis tentang dunia kerja dan alternatif pendidikan dimasa yang akan datang. 
Teknik Problem Solving memiliki langkah-langkah pemecahan masalah secara sistematis. Langkah-langkah pemecahan masalah dengan teknik problem solving adalah mengidentifikasi dan merumuskan masalah; mencari sumber dan memperkirakan sebab-sebab masalah; mencari alternatif pemecahan masalah; menguji kekuatan-kekuatan dan kelemahankelemahan masing-masing alternatif; memilih dan melaksanakan alternatif yang paling menguntungkan dan mengadakan penilaian terhadap hasil yang dicapai. Oleh sebab itu teknik ini dirasa paling sesuai digunakan dalam membantu siswa meningkatkan orientasi pilihan karier mereka.

Berdasarkan latar belakang masalah di atas maka penulis mengadakan penelitian dengan judul "Meningkatkan Orientasi Pilihan Karier Melalui Layanan Bimbingan Kelompok dengan Teknik Problem Solving pada Siswa Kelas XII TPm 2 SMK Negeri 1 Trenggalek Tahun Pelajaran 2016/2017".

\section{METODE}

Rancangan penelitian tindakan bimbingan dan konseling mengacu pada model yang dikembangkan oleh Hopkins (Arikunto, 2006) yang terdiri atas berbagai kegiatan yakni perencanaan (planning), tindakan (acting), observasi (observing), dan refleksi (reflecting). Penelitian ini dilakukan di SMK Negeri 1 Trenggalek. Subyek penelitian ini adalah siswa kelas XII TPm 2 yang berjumlah 36 siswa. Kelas ini dipilih sebagai subyek penelitian karena sebagian besar siswa kelas XII TPm 2 SMK Negeri 1 Trenggalek masih memiliki orientasi pilihan karier yang belum jelas setelah lulus dari SMK (berdasarkan data dari hasil analisis Daftar Cek Masalah dan hasil wawancara dengan siswa).

Instrumen yang digunakan untuk mengetahui tingkat orientasi pilihan karier siswa dalam penelitian ini adalah instrumen non tes. Instrumen non tes pertama adalah berupa angket pilihan karier yang dibagikan kepada peserta didik. Angket ini terdiri dari 20 pernyataan yang terdiri dari 10 pernyataan positif dan 10 pernyataan negatif dengan alternatif jawaban SS (Sangat Setuju), S (Setuju), TS (Tidak Setuju), STS (Sangat Tidak Setuju). Instrumen non tes yang kedua adalah pedoman observasi yang digunakan oleh kolaborator untuk memantau aktifitas siswa selama kegiatan layanan diberikan, berbentuk skala penilaian. Metode pengumpulan data pada penelitian tindakan Bimbingan dan Konseling ini pada prinsipnya tidak berbeda dengan penelitian lainnya, baik data kualitatif maupun data kuantitatif yang dimanfaatkan untuk menggambarkan perubahan yang terjadi, perubahan diri siswa atau perubahan suasana lingkungan kelas atau sekolah.

Analisis data dilakukan secara bertahap dengan cara menyeleksi, mengelompokkan, memaparkan atau mendiskripsikan serta menyimpulkan atau memberikan makna pada Penelitian Tindakan Bimbingan dan Konseling ini, dengan cara memberikan gambaran lebih jelas dan lengkap mengenai suatu gejala atau peristiwa yang sedang diteliti menggunakan persentase.

Kesimpulan diambil apabila sudah dilaksanakan refleksi terhadap tindakan yang dilakukan. Jumlah siklus didasarkan pada hasil refleksi tersebut, apakah sudah memberikan 
informasi/jawaban atas permasalahan yang dikembangkan ada dua yaitu (1) angket pilihan karier dan (2) lembar pengamatan aktifitas siswa.

Dalam angket pilihan karier diberikan 20 pernyataan yang terdiri dari 10 pernyataan positif dan 10 pernyataaan negatif dengan 4 alternatif pilihan jawaban dimana masing-masing jawaban diberikan skor rentangan dari angka 1 sampai dengan 4. Berikut ini adalah tabel penskoran angket pilihan karier siswa.

Tabel 1. Penskoran Angket Pilihan Karier

\begin{tabular}{lcc}
\hline \multicolumn{1}{c}{ Jawaban } & Skor $(+)$ & Skor $(-)$ \\
\hline Sangat Setuju (SS) & 4 & 1 \\
\hline Setuju (S) & 3 & 2 \\
\hline Tidak setuju (TS) & 2 & 3 \\
\hline Sangat Tidak Setuju (STS) & 1 & 4 \\
\hline
\end{tabular}

Jawaban siswa kemudian dijumlahkan dan dikonversikan dalam kategori sebagai

berikut
$71-80$
: Sangat Tinggi
$61-70$
: Tinggi
$41-60$
: Cukup Tinggi
$\geq 40$
: Rendah

Adapun indikator keberhasilan penelitian ini adalah apabila frekuensi angket pilihan karier siswa menunjukkan angka 75\% siswa yang mencapai kategori tinggi dan sangat tinggi. Peneliti juga menggunakan lembar pengamatan aktivitas siswa ketika layanan dilaksanakan, berupa skala penilaian aktifitas kelas dalam kegiatan bimbingan kelompok dengan teknik problem solving. Indikator yang diamati antara lain adalah partisipasi siswa, keaktifan siswa, etika berargumentasi dan pemahaman siswa.

Tabel 2. Skala Penilaian Aktifitas Kelas dalam Kegiatan Bimbingan Kelompok dengan Teknik Problem Solving

\begin{tabular}{|c|c|c|c|c|c|}
\hline NO. & INDIKATOR & Sangat Baik & Baik & Cukup & Kurang \\
\hline 1 & $\begin{array}{l}\text { Partisipasi (antusiasme mengikuti kegiatan } \\
\text { bimbingan) }\end{array}$ & & & & \\
\hline 2 & $\begin{array}{l}\text { Keaktifan (dalam berpendapat dan } \\
\text { menjawab) }\end{array}$ & & & & \\
\hline 3 & $\begin{array}{l}\text { Etika berargumentasi (menghargai } \\
\text { pendapat orang lain) }\end{array}$ & & & & \\
\hline 4 & $\begin{array}{l}\text { Pemahaman (penyelesaikan tugas } \\
\text { kelompok) }\end{array}$ & & & & \\
\hline
\end{tabular}

Skala penilaian di atas terdiri dari 4 kriteria yaitu sangat baik, baik, cukup dan kurang. Hasil pengamatan di atas kemudian dijumlahkan dan dikonversikan dengan kategori berupa banyaknya siswa yang menunjukkan perilaku sesuai dengan indikator yang ditentukan, yaitu :

$\begin{array}{ll}34-36 \text { siswa } & \text { Sangat Baik } \\ 28-33 \text { siswa } & \text { Baik } \\ 23-27 \text { siswa } & \text { Cukup } \\ \geq 22 \text { siswa } & \text { Kurang }\end{array}$


Layanan bimbingan kelompok dengan teknik problem solving dalam meningkatkan orientasi pilihan karier siswa dianggap berhasil jika skala penilaian tersebut untuk semua indikator skornya berada pada kategori baik dan atau sangat baik.

HASIL

Pada tahap perencanaan peneliti membuat jadwal kegiatan penelitian, mempersiapkan RPLBK dan instrumen yang akan digunakan untuk penelitian, terdiri dari angket pilihan karier dan pedoman observasi berupa skala penilaian aktivitas kelas dalam kegiatan bimbingan kelompok dengan teknik problem solving.

Pada tahap pelaksanaan layanan bimbingan kelompok dengan teknik problem solving siklus I dilaksanakan pada hari Senin tanggal 19 September 2016 kepada siswa kelas XII TPm 2 SMK Negeri 1 Trenggalek. Pada siklus I ini peneliti melakukan bimbingan kelompok dengan materi "Orientasi Pilihan Karier". Peneliti/konselor membina hubungan baik dengan mengajak siswa mengungkapkan tujuan dan harapan-harapan yang ingin dicapai. Selanjutnya konselor memberikan penjelasan tentang langkah-langkah kegiatan bimbingan kelompok dengan teknik problem solving dan memberikan penjelasan mengapa kegiatan ini perlu dilakukan. Konselor kemudian membagi kelas menjadi 6 kelompok, dimana masing-masing kelompok terdiri dari 6 siswa.

Dari hasil pelaksanaan menghasilkan data frekuensi pilihan karier siswa siklus I yang dapat dilihat pada Tabel 3.

Tabel 3. Frekuensi Pilihan Karier Siswa pada Siklus I

\begin{tabular}{ccccc}
\hline No & Skor Perolehan & Frekuensi & Frekuensi (\%) & Kategori \\
\hline 1. & $\leq 40$ & 0 & $0 \%$ & Rendah (R) \\
\hline 2. & $51-60$ & 11 & $30,56 \%$ & Sedang (S) \\
\hline 3. & $61-70$ & 18 & $50,00 \%$ & Tinggi (T) \\
\hline 4 & $71-80$ & 7 & $19,44 \%$ & Sangat Tinggi (ST) \\
\hline & Jumlah & $\mathbf{3 6}$ & $\mathbf{1 0 0 \%}$ & \\
\hline
\end{tabular}

Dari tabel di atas dapat diketahui bahwa persentase hasil angket pilihan karier siswa untuk kategori sedang adalah $30,56 \%$, kategori tinggi $50,00 \%$, dan kategori sangat tinggi $19,44 \%$. Hal ini berarti persentase pilihan karier siswa yang diajukan di awal penelitian masih belum tercapai, karena jumlah persentase untuk kategori tinggi dan sangat tinggi hanya sebesar $69,44 \%(50 \%+19,44 \%)$ dan masih berada dibawah persentase ketuntasan/ kriteria keberhasilan yang ditetapkan yaitu $75 \%$.

Selain dari hasil pelancaran angket, peneliti juga mengamati aktivitas kelas dalam kegiatan layanan bimbingan kelompok dengan teknik problem solving. Berikut ini adalah hasil pengamatan terhadap layanan bimbingan kelompok pada siklus I. 
Tabel 4. Hasil Observasi Aktivitas Kelas dalam Layanan Bimbingan Kelomok dengan Teknik Problem Solving Siklus I

\begin{tabular}{|c|c|c|c|c|c|}
\hline NO. & INDIKATOR & $\begin{array}{l}\text { Sangat } \\
\text { Baik }\end{array}$ & Baik & Cukup & Kurang \\
\hline 1 & $\begin{array}{l}\text { Partisipasi (antusiasme mengikuti kegiatan } \\
\text { bimbingan) }\end{array}$ & & $\sqrt{ }$ & & \\
\hline 2 & $\begin{array}{l}\text { Keaktifan (dalam berpendapat dan } \\
\text { menjawab) }\end{array}$ & & & $\sqrt{ }$ & \\
\hline 3 & $\begin{array}{l}\text { Etika berargumentasi (menghargai } \\
\text { pendapat orang lain) }\end{array}$ & & $\sqrt{ }$ & & \\
\hline 4 & $\begin{array}{l}\text { Pemahaman (penyelesaikan tugas } \\
\text { kelompok) }\end{array}$ & & & $\sqrt{ }$ & \\
\hline
\end{tabular}

Dari tabel di atas dapat diketahui bahwa masih ada dua indikator yang termasuk dalam kategori cukup yaitu keaktifan dan pemahaman siswa. Untuk itu konselor/ peneliti akan berusaha lebih memaksimalkan layanan pada siklus II agar semua indikator masuk dalam kategori baik atau sangat baik.

Dari hasil pengamatan terhadap angket pilihan karier siswa diperoleh hasil bahwa terdapat 11 siswa atau 30,56\% termasuk dalam kategori sedang, 18 siswa atau 50,00\% termasuk kategori tinggi, dan 7 siswa atau 19,44\% termasuk dalam kategori sangat tinggi. Hal ini berarti persentase orientasi pilihan karier siswa masih berada di bawah persentase yang ditetapkan di awal penelitian. Frekuensi persentase angket pilihan karier siswa yang termasuk kategori baik dan sangat baik hanya $69,44 \%$ masih berada dibawah persentese yang ditetapkan yaitu $75 \%$. Selain itu hasil observasi aktifitas kelas dalam kegiatan bimbingan kelompok dengan teknik problem solving menunjukkan 2 indikator berada dalam kategori cukup, artinya belum mencapai ketuntasan yang ditetapkan (semua indikator berada dalam kategori baik atau sangat baik). Untuk itu peneliti merencakan tindakan berikutnya dengan merevisi hal-hal yang kurang mendapat perhatian dari siswa, yaitu melaksanakan layanan bimbingan kelompok siklus 2 .

\section{Siklus 2}

Pada tahap perencanaan peneliti mempersiapkan RPLBK dan instrumen yang akan digunakan, yaitu angket pilihan karier siswa dan pedoman observasi berupa skala penilaian aktifitas kelas dalam layanan bimbingan kelompok dengan teknik problem solving.

Pada tahap pelaksanaan layanan bimbingan kelompok siklus 2 dengan teknik problem solving dilaksanakan pada hari Senin tanggal 26 September 2016 pada siswa kelas XII TPm 2 SMK Negeri 1 Trenggalek. Pada siklus 2 ini peneliti memberikan materi bimbingan tentang orientasi jenis-jenis pekerjaan sesuai tipe kepribadian. Dari hasil pelaksanaan menghasilkan data frekuensi pilihan karier siswa siklus II yang dapat dilihat pada Tabel 5.

Tabel 5. Frekuensi Pilihan Karier Siswa pada Siklus II

\begin{tabular}{cccccl}
\hline No & & Skor Perolehan & Frekuensi & Frekuensi \% & \multicolumn{1}{c}{ Kategori } \\
\hline 1. & $\leq 40$ & 0 & $0 \%$ & Rendah (R) \\
\hline 2. & $51-60$ & 4 & $11,11 \%$ & Sedang (S) \\
\hline 3. & $61-70$ & 21 & $58,33 \%$ & Tinggi (T) \\
\hline 4. & $71-80$ & 11 & $30,56 \%$ & Sangat Tinggi (ST) \\
\hline & Jumlah & 36 & $100 \%$ & \\
\hline
\end{tabular}


Dari tabel di atas dapat diketahui bahwa persentase hasil angket pilihan karier siswa untuk kategori sedang adalah $11,11 \%$, kategori tinggi 58,33\%, dan kategori sangat tinggi $30,56 \%$. Hal ini berarti persentase pilihan karier siswa yang diajukan di awal penelitian telah tercapai, dimana jumlah persentase kategori tinggi dan sangat tinggi sebesar $88,89 \%$ (58,33\% $+30,56 \%$ ) di atas persentase ketuntasan yang ditetapkan yaitu $75 \%$.

Selain memberikan angket pilihan karier, peneliti juga mengamati aktivitas layanan bimbingan kelompok dengan teknik problem solving. Berikut ini adalah hasil analisis bimbingan kelompedoman observasi berupa skala penilaian aktifitas kelas dalam kegiatan layanan bimbingan kelompok dengan teknik problem solving pada siklus II.

Tabel 6. Hasil Observasi Aktivitas Kelas dalam Layanan Bimbingan Kelompok dengan Teknik Problem Solving Siklus II

\begin{tabular}{|c|c|c|c|c|c|}
\hline NO. & INDIKATOR & Sangat Baik & Baik & Cukup & Kurang \\
\hline 1 & $\begin{array}{l}\text { Partisipasi (antusiasme mengikuti kegiatan } \\
\text { bimbingan) }\end{array}$ & $\sqrt{ }$ & & & \\
\hline 2 & $\begin{array}{l}\text { Keaktifan (dalam berpendapat dan } \\
\text { menjawab) }\end{array}$ & & $\sqrt{ }$ & & \\
\hline 3 & $\begin{array}{l}\text { Etika berargumentasi (menghargai pendapat } \\
\text { orang lain) }\end{array}$ & $\sqrt{ }$ & & & \\
\hline 4 & $\begin{array}{l}\text { Pemahaman (penyelesaikan tugas } \\
\text { kelompok) }\end{array}$ & & $\sqrt{ }$ & & \\
\hline
\end{tabular}

Dari tabel di atas dapat diketahui bahwa tidak terdapat indikator yang termasuk kategori cukup atau kurang, bahkan terdapat dua indikator yang termasuk kategori sangat baik dan dua indikator lainnya termasuk kategori baik. Hal ini berarti kegiatan bimbingan kelompok dengan teknik problem solving pada siklus II ini berhasil.

Dari hasil pengamatan terhadap angket pilihan karier siswa diperoleh hasil bahwa terdapat 4 siswa atau 11,\% termasuk dalam kategori sedang, 21 siswa atau 58,33\% termasuk kategori tinggi, dan 11 siswa atau 36,56\% termasuk dalam kategori sangat tinggi. Hal ini berarti persentase orientasi pilihan karier siswa telah melebihi persentase yang ditetapkan di awal penelitian karena frekuensi persentase angket pilihan karier siswa yang termasuk kategori baik dan sangat baik sebesar $88,89 \%$ di atas persentese yang ditetapkan yaitu $75 \%$. Selain itu hasil observasi juga menunjukkan bahwa semua indikator berada dalam kategori baik dan sangat baik sehingga dapat disimpulkan bahwa kegiatan layanan bimbingan kelompok dengan teknik problem solving dapat meningkatkan orientasi pilihan karier siswa. Oleh karena itu peneliti tidak merencanakan tindakan atau siklus selanjutnya.

\section{PEMBAHASAN}

Melalui bimbingan kelompok dengan teknik problem solving dapat meningkatkan orientasi pilihan karier siswa, karena dalam kegiatan bimbingan kelompok dengan teknik problem solving memungkinkan siswa menyampaikan permasalahan serta pendapat yang tidak bisa tersampaikan. Dalam kegiatan ini juga dilakukan dengan suasana yang menyenangkan seperti suasana rumah sehingga diharapkan siswa tidak merasa terpaksa atau tertekan pada saat menyampaikan permasalahan dan pendapatnya. Dari hal tersebut siswa akan memperoleh berbagai pengalaman, pengetahuan dan gagasan. Dari topik itu pula siswa bisa 
belajar mengembangkan nilai-nilai dan menerapkan langkah-langkah bersama untuk mencapai tujuan bimbingan yang ditetapkan.

Hasil analisis data menunjukkan bahwa terjadi peningkatan orientasi pilihan karier siswa antara sebelum dan sesudah dilakukan bimbingan kelompok dengan teknik problem solving. Pada siklus I, dari 36 siswa menunjukkan tingkat pilihan karier yang berbeda-beda. Diantaranya 7 siswa atau 19,44\% menunjukkan orientasi pilihan karier yang sangat tinggi, 18 siswa atau 50\% menunjukkan orientasi pilihan karier yang tinggi, dan 11 siswa atau 30,56\% menunjukkan orientasi pilihan karier yang sedang. Pada siklus I persentase ketuntasan orientasi pilihan karier siswa masih belum tercapai karena persentase jumlah orientasi pilihan karier siswa pada kategori tinggi dan sangat tinggi hanya mencapai $69,44 \%$ masih berada di bawah kriteria persentase yang ditetapkan yaitu $75 \%$, oleh karena itu peneliti merencanakan kegiatan siklus 2 .

Pada kegiatan siklus 2 menunjukkan adanya peningkatan orientasi pilihan karier siswa. Dari 36 siswa kelas XII TPm 2 terdapat 11 siswa atau 30,56\% menunjukkan orientasi pilihan karier yang sangat tinggi, 21 siswa atau 58,33\% menunjukkan orientasi pilihan karier yang tinggi, dan 4 siswa atau 11,11\% menunjukkan orientasi pilihan karier yang sedang. Pada siklus 2 persentase ketuntasan yang ditetapkan telah tecapai karena jumlah persentase kategori tinggi dan sangat tinggi sebesar $88,89 \%$ di atas persentase ketuntasan yang ditetapkan yaitu $75 \%$ sehingga dapat dikatakan bahwa penelitian ini dianggap berhasil dan hipotesis yang diajukan di awal penelitian ini dapat diterima.

\section{KESIMPULAN DAN SARAN}

Berdasarkan hasil penelitian dan pembahasan yang telah diuraikan, maka dapat dihasilkan beberapa kesimpulan bahwa layanan Bimbingan Kelompok dengan teknik problem solving mampu meningkatkan orientasi pilihan karier siswa. Selain itu juga meningkatkan keaktifan siswa terhadap layanan bimbingan konseling di sekolah dan rasa tertarik untuk berkonseling. Hal ini ditunjukkan dari perubahan perilaku siswa pada setiap pertemuan bimbingan kelompok telah mengarah pada peningkatan minat terhadap layanan yang diberikan yaitu lebih baik dari sebelumnya. Selain itu diketahui dari hasil analisis angket pilihan karier siswa yang menunjukkan bahwa tingkat orientasi pilihan karier siswa termasuk dalam kategori tinggi. Hal tersebut dilengkapi dengan data hasil observasi yang menunjukkan bahwa partisipasi dan etika berargumentasi siswa sangat tinggi dan keaktifan siswa serta pemahaman materi yang tinggi.

Saran dari hasil penelitian ini adalah guru pembimbing hendaknya mengaktifkan kegiatan layanan bimbingan kelompok dalam usaha membantu siswa menyelesikan permasalahan yang dimiliki, sehingga siswa dapat berkembang sesuai dengan tugas perkembanganya, mampu mengembangkan diri, dapat menunjukkan potensi yang dimilikinya, belajar mengungkapkan pendapat, menghargai orang lain dan tenggang rasa. Selain itu guru pembimbing hendaknya aktif melakukan penelitian dalam rangka meningkatkan efektifitas layanan bimbingan dan konseling di sekolah. 


\section{DAFTAR RUJUKAN}

Slameto. 2008. Belajar dan Faktor-faktor yang Mempengaruhinya. Jakarta : Rineka Cipta.

Arikunto. 2006. Prosedur Penelitian Suatu Pendekatan Praktek. Jakarta: Rineka Cipta.

Arikunto. 2006. Prosedur Penelitian Suatu Pendekatan Praktek. Jakarta: Rineka Cipta.

Aristiani. 2005. Keefektifan Layanan Bimbingan Kelompok dan Layanan Bimbingan

Belajar dalam meningkatkan Perencanaan Karir Siswa kelas I SMKN 1 Semarang.

Program Studi BK UNNES (Skripsi tidak diterbitkan).

Romlah, Tatiek. 2001. Teori dan Praktek Bimbingan Kelompok. Surabaya: UM. 